\author{
Krzysztof Lewandowski \\ Dr inż. \\ Politechnika Wrocławska \\ Krzysztof.lewandowski@pwr.edu.pl
}

DOI: 10.35117/A_ENG_19_04_02

\title{
Proposal to build new roads for rail transport in Lower Silesia
}

\begin{abstract}
The aim of this article is presentation for build the new tracks connections for the rail transport in the region of the Lower Silesia, two for trains, one for tramways. All of them have the goal to betterment of the communication and reducing the time of the journey. They needs to additional analysis but allowed despite relatively the big preliminary capital expenditure they betterment of the offer of the rail transport. This is conductive to reduce the environmental burden by the emission of exhaust gases from the modes of the transport.
\end{abstract}

Keywords: New tracks; Lower Silesia; Betterment; Offer; Public transport

\section{Introduction}

The current rail transport network in Lower Silesia is based on the railway lines that were found after the end of World War II and forced by the Yalta Conference to change the borders of Poland. The modernization of railway lines, which has been carried out for several years, concerns mainly the improvement of the quality of railway tracks, signalling, traffic control and infrastructure at passenger stations and stops. However, in Lower Silesia there are places where these modernizations will not change the traffic organization and will not broaden the public transport offer for the inhabitants of the region. These are places where it is based on old railway lines. It would be sufficient to make additional new investments which would significantly change the rail transport offer.

\section{Proposal for the construction of a link for the Wegliniec Lubań route}

Węgliniec is one of the oldest railway stations in Lower Silesia. It was founded in 1846. The Polish name Węgliniec has been used since 1947. The station was electrified in 1979. Currently, several railway lines pass through the station:

a) Railway line no. 275 Wrocław Muchobór - Gubinek,

b) Railway line no. 278 Węgliniec - Zgorzelec,

c) Railway line no. 279 Węgliniec - Lubań Śląski,

d) Railway line no. 282 Miłkowice - Węgliniec - Żary - Jasień,

e) Railway line no. 295 Węgliniec - state border - Horka.

The route to Lubań Śląski with the number 279 in the Network Timetable (SRJ) was put into service in 1865. In 1928 it was electrified with AC voltage of $15000 \mathrm{~V}$ and frequency of 16 $2 / 3 \mathrm{~Hz}$. In 1945, the electricity grid was disconnected by the Soviet Army. After World War II, the second track was also removed. In 1986 the line was electrified again with the direct current of 3000V [3].

At present, the passenger train from Lubań to Węgliniec takes about 30 minutes to travel. Each Wrocław - Lubań Śląski train requires a stop at the Węgliniec station, which is about 10 minutes long. This results from the fact that line 279 departs from the station Weggliniec to Luban in the direction opposite to the direction of arrival from Wrocław. At the station, a change of direction is necessary, and this requires the driver to pass through the entire length 
of the train to the second control cabin. In order to shorten the travel time from Węgliniec to Lubań, the construction of a connecting line should be considered. The Liaison would start at the station Wegliniec and would initially run along the railway line no. 295 Wegliniec - state border - Horka. In place of the old railway siding to the old brown coal mine Kaławsk (German: Unirubber) in Zielonka, a turnout and a siding track should be reconstructed (Fig. 1).

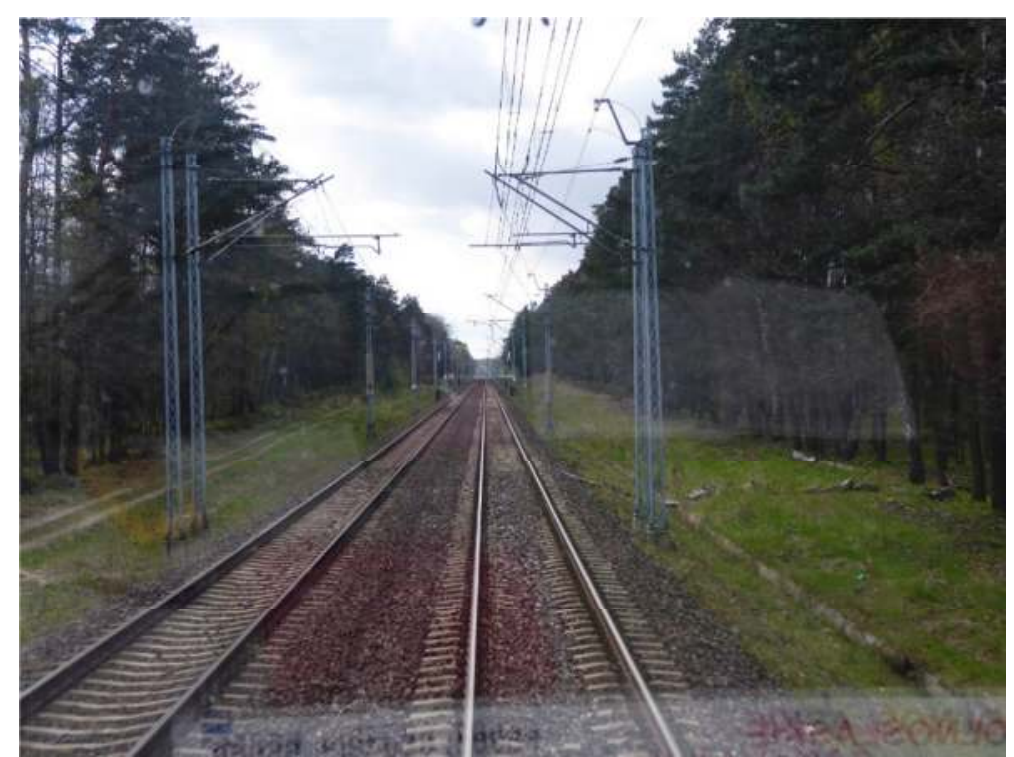

1. View from the cabin of the rail bus in the place of the old railway siding to Zielonka on the left side

Further, following the siding, the liaison would turn, on the embankment, in the direction of the route to Lubań, passing via viaducts over the railway line no. 278 Węgliniec - Zgorzelec and DW no. 296. After bypassing from the south of Węgliniec, the single-track liaison, about $8 \mathrm{~km}$ long, would join the railway line no. 279 Węgliniec - Lubań Śląski on the siding track and the junction with the applied signalling. The bridgehead could initially be located on the footprint of the track dismantled in 1945, and over time as an additional third track (Figure 2, $\mathbf{3 , 4}$ ). The construction cost of this solution is about PLN 30 million.

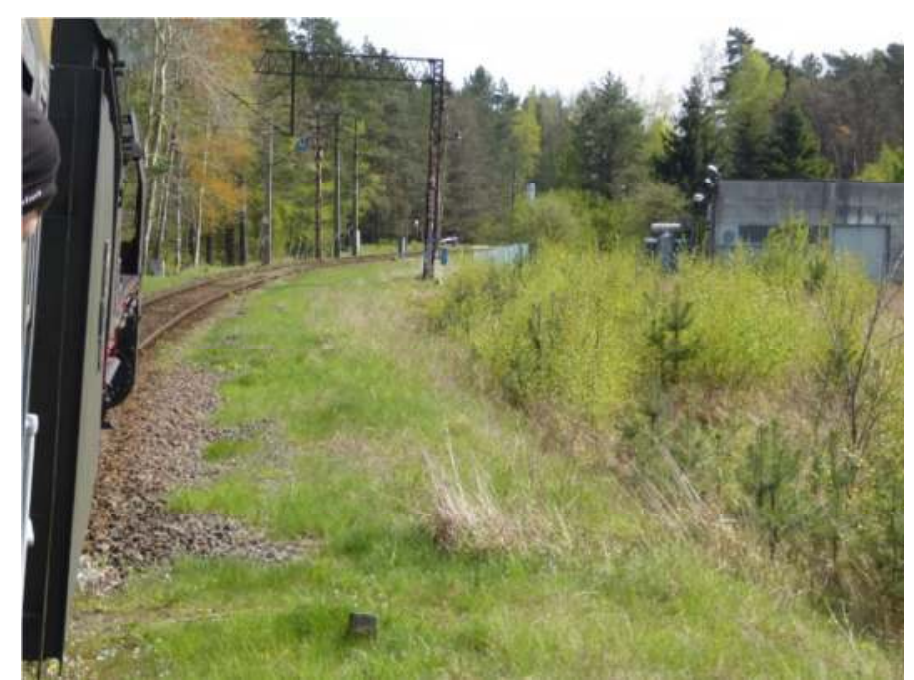

2. Departure from Węgliniec to Lubań 


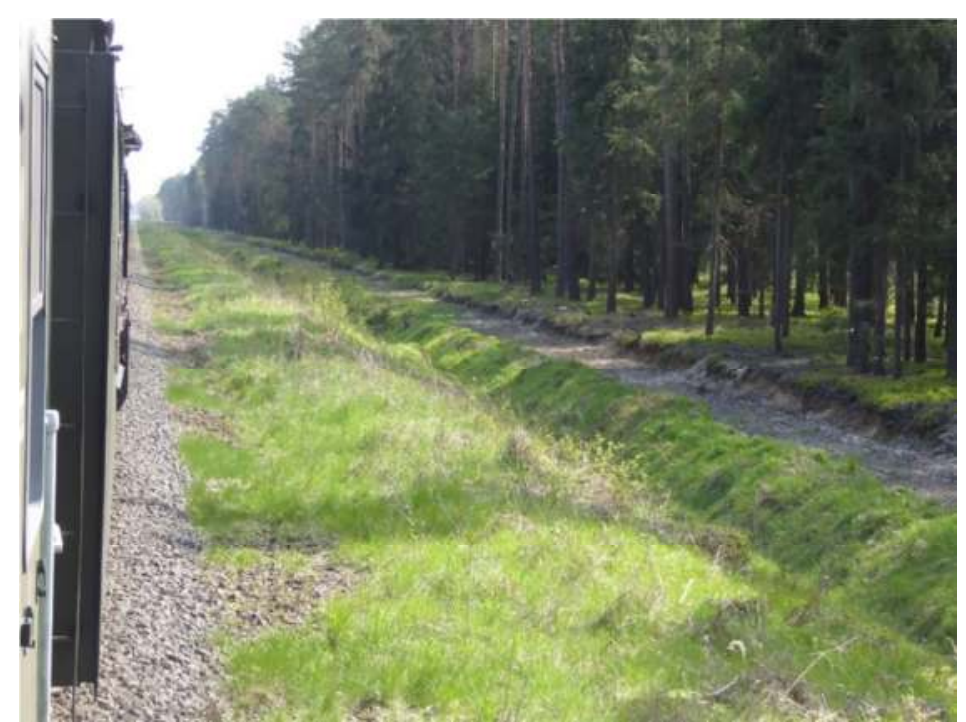

3. Traces of the second track on railway line 279 Węgliniec - Lubań Śląski

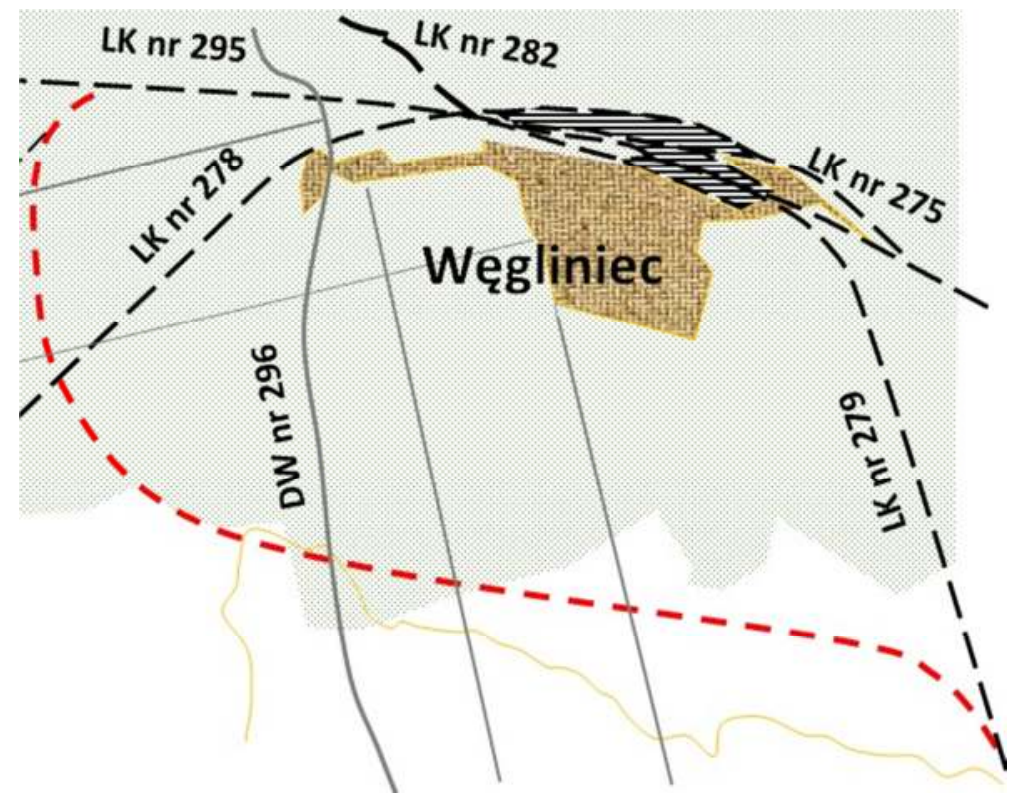

4. Proposed route for the Węgliniec Lubań route

The link would allow to shorten the time of train journey from Wrocław to Lubań through the Węgliniec station from about 5 to even 8 minutes. Trains between Wrocław and Lubań Śląski would only require a stop at Węgliniec to exchange passengers, not to change the direction of travel. Thus, it would measurably improve the communication and shorten the total time of train travel between Wrocław and Lubań Śląski. Similar solutions are present in Lower Silesia, e.g. the active railway line no. 751 Wrocław Gądów - Wrocław Zachodni or the already dismantled railway line in the area of the Marciszów station for trains on line no. 302 to Bolków [3].

\section{Proposal to change the route between Kobierzyce and Ząbkowice Śląskie}

The planned modernization of the railway line no. 285 between Wrocław and Świdnica with passages in Bielany Wrocławskie and Sobótka Zachodnia [5] and the declaration of taking over the right of perpetual usufruct of land and ownership of buildings and equipment 
connected with railway lines no. 284, 291, 310, 318 and 327 [7] for the benefit of the Lower Silesian Voivodeship Self-Government, allows us to conclude that it gives the possibility of improving access from Wrocław to Ząbkowice Śląskie. Ząbkowice Śląskie is one of the oldest towns in Lower Silesia. It was founded in the second half of the 13th century. It currently numbers about 15 thousand people [4].

Communication is provided by:

- national road No. 8 (Warsaw - Piotrków Trybunalski - Wrocław - Kudowa-Zdrój)

- voivodship road no. 382 (Paczków - Świdnica)

- voivodship road no. 385 (Nowa Ruda - Ziębice)

- local roads to Bobolice, Czerńczyce, Piława Górna

- railway line no. 137 from Katowice to Legnica.

Currently, to get by train from Wroclaw to Ząbkowice Śląskie you need to use trains via Kamieniec Ząbkowicki on the route to Kłodzko or trains via Jaworzyna Śląska on the route to Jelenia Góra. Travel time to Ząbkowice Śląskie via Kamieniec Ząbkowicki is about 1h20 minutes. The journey through Jaworzyna Śląska takes almost 2 hours. In order to improve this time, it is worth considering the construction of two railway sidings as part of the renovation of railway line no. 285 between Wrocław and Świdnica. It is assumed that the railway line no. 310 Kobierzyce - Bielawa Górna, which is currently overgrown and impassable on its entire length, will be used (Fig. 5). The $40 \mathrm{~km}$ long route leads, among others, through Jordanów Śląski, Łagiewniki, Niemcza and Przerzeczyn

Zdrój to Piława Górna [3].

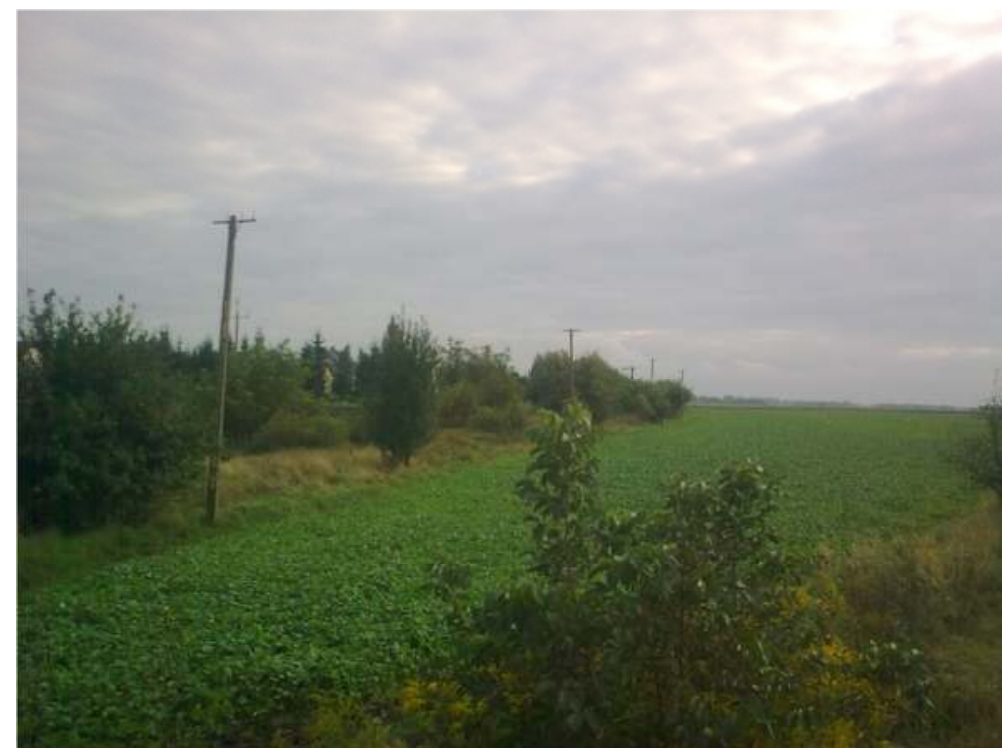

5. Railway track of railway line no. 310 Kobierzyce -Bielawa Górna seen at the exit from Kobierzyce to Sobótka on line no. 285

The first possible route of the connecting line no. 1 would lead from Przerzeczyn Zdrój on the railway line no. 310 Kobierzyce - Bielawa Górna to the railway line no. 320 Ząbkowice Śląskie - Kondratowice through the picturesque valley of the Ślęza river springs (fig. 6, 7). It would be about $5.5 \mathrm{~km}$ long. The disadvantage of this solution is the crossing of national road No. 8 and very narrow arches at the station in Przerzeczyn Zdrój. 


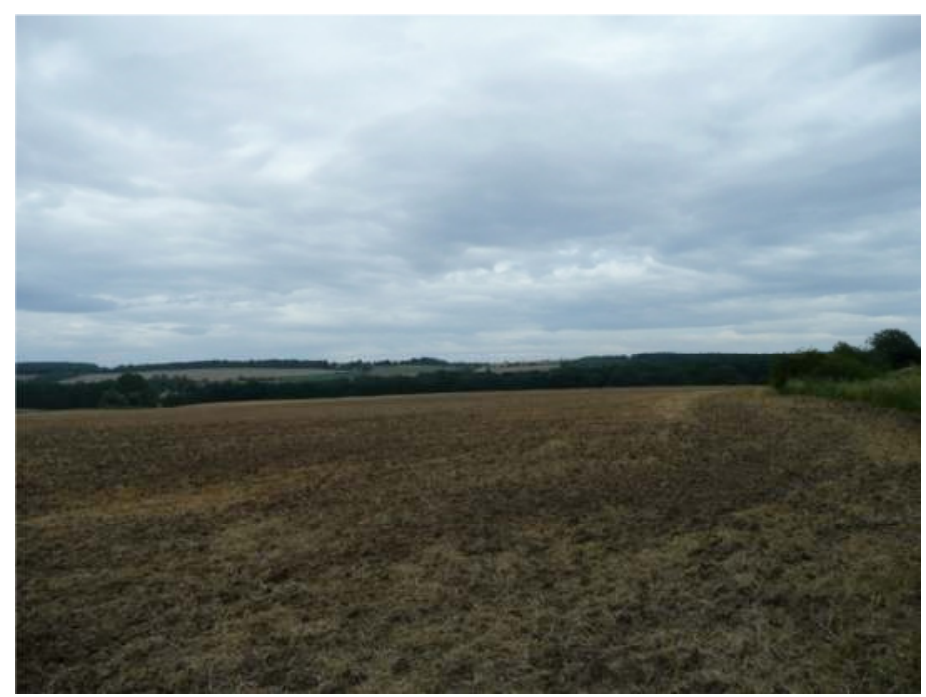

6. View towards Kondratowice from the intersection of the railway line No. 320 with the road to Ciepłowodów

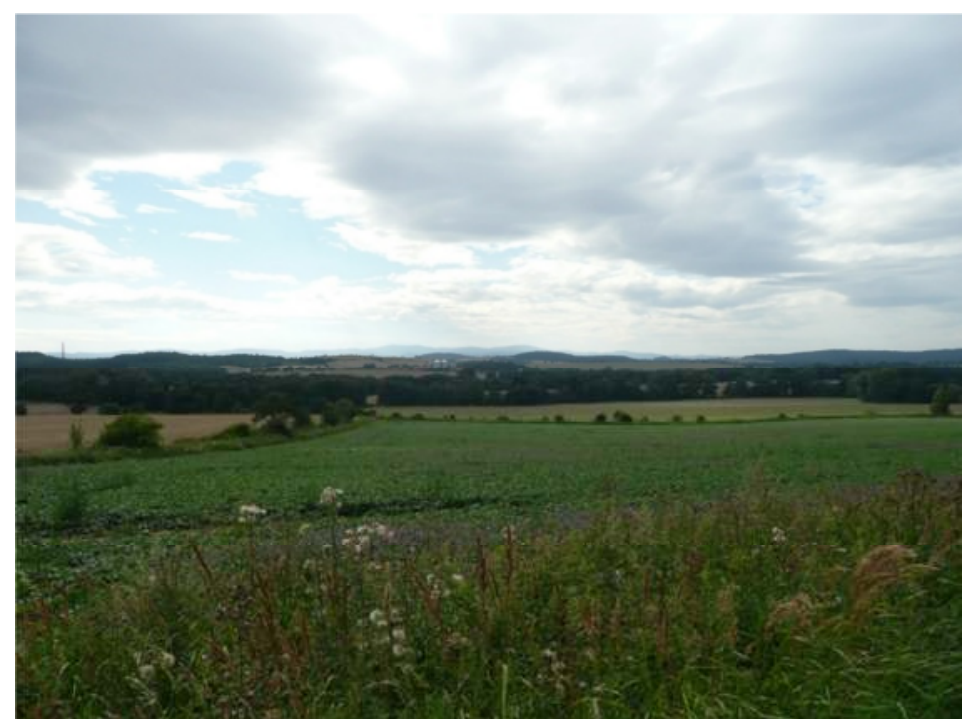

7. View towards Przerzeczyn Zdroj through the Ślęza river valley

The second possible route of the liaison no. 1, with a length of about $5.5 \mathrm{~km}$, would lead from Przerzeczyn Zdrój on the railway line no. 310 Kobierzyce - Bielawa Górna to the area of Szklary to connect with the former one, dismantled in 2014. [2], railway line 320 Ząbkowice Śląskie - Kondratowice. This connection makes it possible to create two new railway stops: Sulisławice-Szklary i Turned. The liaison would lead through the area of iron-nickel slag heaps from the former Nickel, Chryzoprazu and Opal Mines in Szklary. They should be removed, e.g. by offering them as ore and selling them. Current metallurgical technologies make it possible to recover even from very poor ores. The crossing of the Ślęza River tributary should be done on a flyover. In the face of the progressing steppe formation of Poland as a result of climate change - global warming, the routing of this part of the line must take into account the protection of water sources and watercourses.

The first possible route of the $\mathrm{n} 2$ liaison line, about $1 \mathrm{~km}$ long, would lead on route 320 to the station in Ząbkowice Śląskie, a new track on the railway bridge over the national road no. 
8 , joining the track no. 1 in the area of the junction no. 28 on the railway line no. 137 (according to Semaforek.pl) at the station in Ząbkowice Śląskie [8].

The second possible route of the link no. 2 would lead through the departure from the track on line 137 behind the viaduct over the national road no. 8 and the cross-cut would connect with the line no. 320. This would allow the reconstruction of the connection to the railway line no. 318 Ząbkowice Śląskie Dworzec Mały - Srebrna Góra and further through Bielawa to Dzierżoniów if there was such a need or will. This solution would avoid the need to build a viaduct on the arch to the station at the Ząbkowice Śląskie station.

This would avoid the need to use the Small Railway Station in Ząbkowice Śląskie, where the original line 320 Ząbkowice Śląskie - Kondratowice and line 318 Ząbkowice Śląskie Dworzec Mały - Srebrna Góra (Figure 8, 9, 10), which was closed at the beginning of the 1990 s, came from. Especially since there is a willingness to take over the section Bielawa Srebrna Góra on line 318 [7], the new line 2 in variant 2 is justified. The cost of building this solution and revitalizing the railway line no. 310, due to earthworks and the new railway flyover on line 137, would amount to approximately PLN 200 million. It is worth noting that it is not excessive since the renovation of the line 285 between Wrocław and Świdnica alone costs about PLN 200 million. 1], and on the Świdnica Kraszowice - Jedlina-Zdrój section it is PLN 109,995 million net with EU co-financing in the amount of PLN 94,295 million. [6].

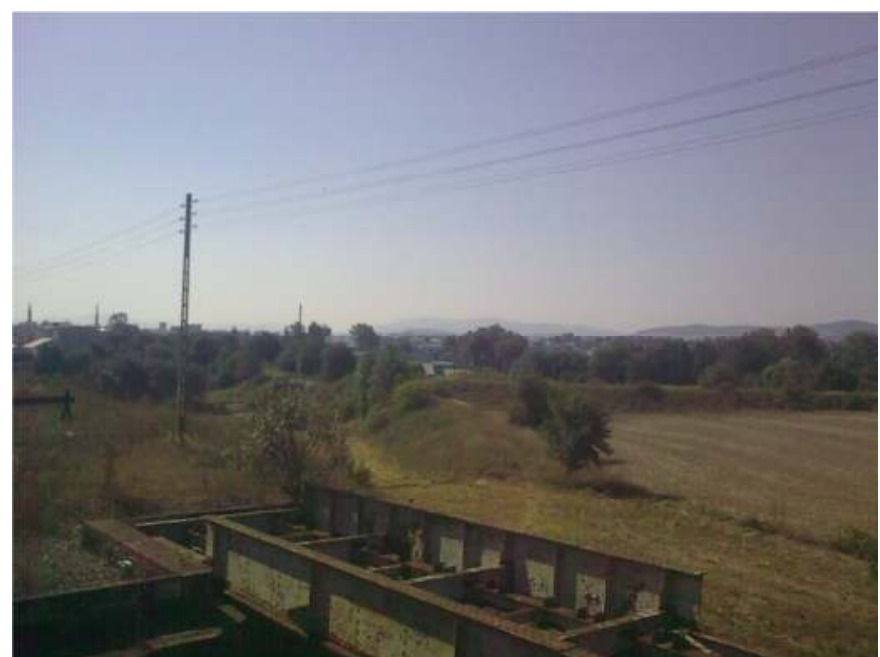

8. Bifurcation of railway lines 318 and 320 at the exit from the Mały Railway Station in Ząbkowice Śląskie seen from above the viaduct on line 137 over line 320 in a southern direction

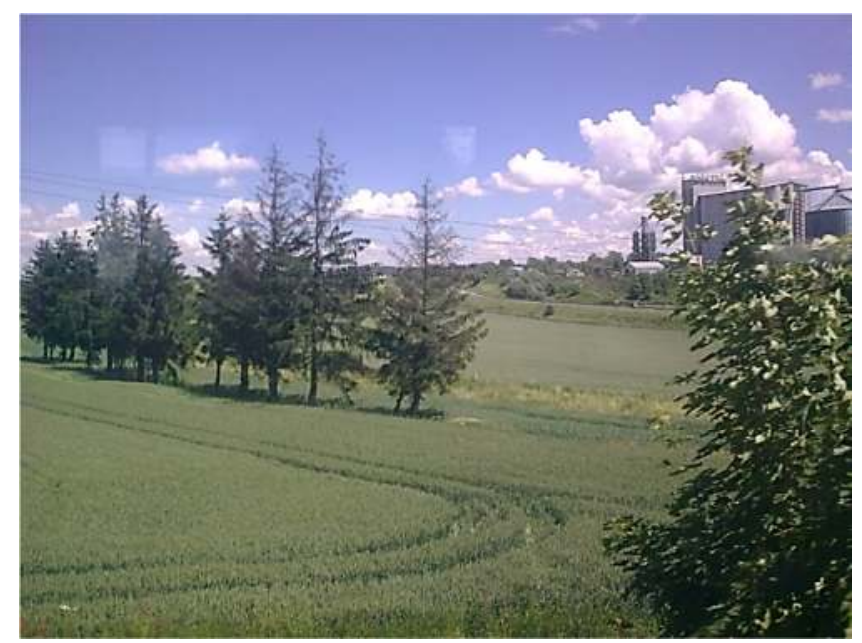


9. The Old Town of the railway line No 320 (light green belt) and national road No 8 seen from the train on the railway line No 137 in the northern direction

The construction of these connecting lines for Kobierzyce Ząbkowice Śląskie would significantly improve communication between all towns along line 310 and shorten the total time of train journeys between Wrocław and Ząbkowice Śląskie. What is more, this will create an emergency route for trains between Wrocław and Kamieniec Ząbkowicki. The execution of a crosscut according to the second variant of connecting line 2 would allow to eliminate the old low railway viaduct for lines 318 and 320 from the Mały Railway Station in Ząbkowice Śląskie. In addition, it will allow to deliver the cut belt at the national road No. 8 for the needs of its extension as part of the planned modernisation to the S-class road.

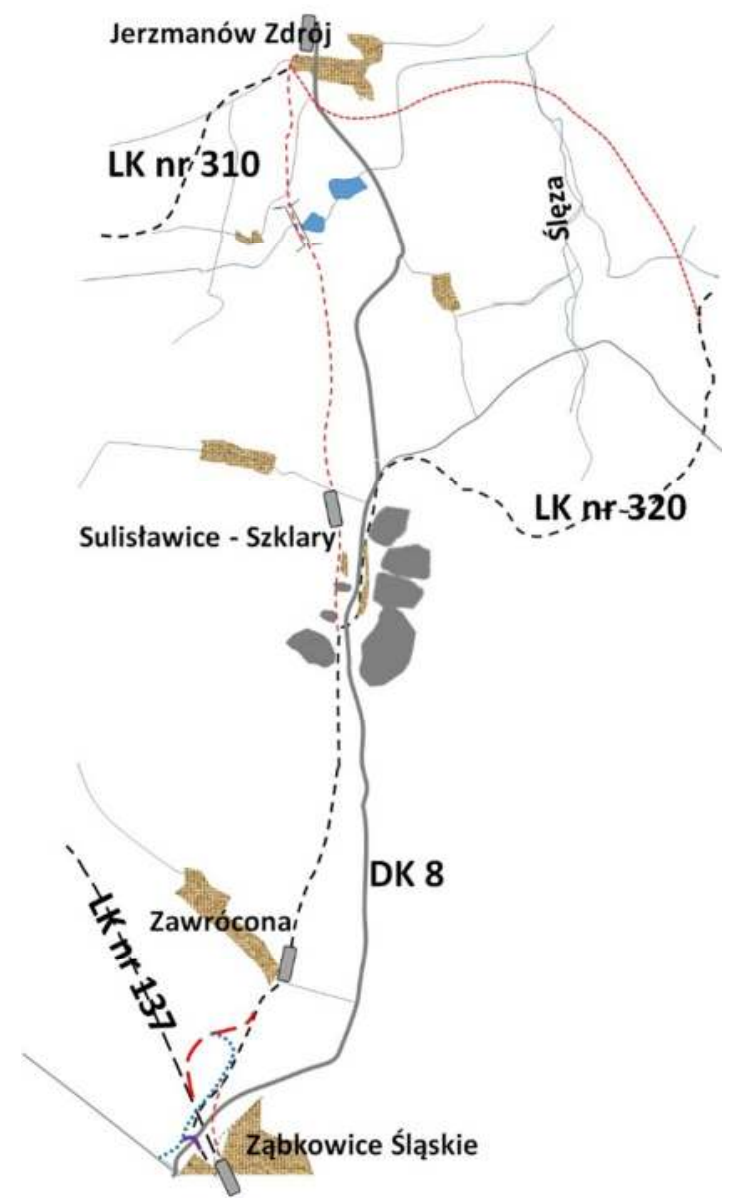

10. Proposed layout of liaison lines between Kobierzyce and Ząbkowice Śląskie

It is therefore reasonable to build another pass in Kobierzyce for rail traffic. Two railway lines 285 and 310 should have separate entrances to the Kobierzyce station when going to Wrocław. Trains from Wrocław should leave as trainsets, i.e. with one train number, and at the station Kobierzyce would separate thanks to automatic couplings. Trains to Ząbkowice Śląskie and Sobótka would leave at short intervals of time required to change the position of switches. On the course to Wrocław, both trains would enter one track, one after the other, and would couple in such a way as to leave as a single train to Wrocław. It is also necessary to provide a pass for freight depots, track 4 . To this end, it is justified to reconstruct track 1, 2 and 4 at Kobierzyce station.

Proposal to build a tram line between the Krzyki stop in Wroctaw and Kobierzyce 
Again, raising the fact of the planned modernization of the railway line no. 285 between Wrocław and Świdnica [5] and the takeover for the benefit of the Nicolaus Copernicus University [7], thesis is that it gives the possibility to improve access to Kobierzyce.

This plan includes designing and execution of first of all reconstruction works with optimization of railway line geometry within the existing (reconstructed) earth structures on the route and within the limits of the track at stations and passenger stops of the single-track railway line No. 285 on the section Wrocław Gł. - Świdnica Przedmieście (from km - 0.108 to km 60.800) and the railway line no. 771 Świdnica Przedmieście - Świdnica Miasto (about km 0.121 to $\mathrm{km} \mathrm{2.165)}$ together with the accompanying infrastructure. The modernization plan for line 285 mentions the construction of one track on this section. He says that the new track will follow in the footsteps of track 1 Wrocław- Kobierzyce. On the whole length no activities are planned on the track footprint of track 2 except for the planned pass in Bielany Wrocławskie [5].

Currently, the freight trains to the station Sobótka Zachodnia via Kobierzyce are connected to the track, which follows sections of track 1 or (i) 2 of the railway line built in 1884. Tor 2 was removed after World War II by the Soviet Army [3].

The idea of building a tram line is based on the analysis of the development of the town along this railway line. In Bielany Wrocławskie, the residential buildings are located along the entire route through this village. It is similar in Domasław and Kobierzyce. After revitalisation, no new railway stops are planned. Therefore, it is reasonable to consider the construction of a classic tram track along the entire section of the Krzyki stop in Wrocław Kobierzyce. The tram track would de facto start at the crossroads of Karkonoska Avenue and Przyjaźni Street where the tram line no. 17 runs. The two-track track would cross Karkonoska Avenue heading towards a wide green belt separating the Soviet Soldiers' Cemetery from the street. Walking along this green belt, over $10 \mathrm{~m}$ wide, the track would reach the vicinity of T34 tanks on pedestals. Here it would turn south and cross the Wyścigowa street and enter the plots of land No. 20/21 and 20/5. There would be a bus stop and a passage to the single-track section. A single track would go parallel to the railway track to the railway track. The basic problem is that it would require crossing the railway track following the track no. 1 on line 285 in order to follow the track no. 2. The solution would be to install an appropriate signalling system for both trains and trams in the vicinity of the Wrocław Partynice station. After agreement with the railway company, the railway track could be moved to the track mark of track no. 2 on a certain section, so that the tram would not be crossed when leaving the stop on plots of land no. 20/21 and 20/5. Only after the Wrocław Partynice station, before the bridge over the Ślęza river, would there be a crossroads where the tram would enter the track in the footsteps of track no. 2 and the train would enter the track in the footsteps of track no. 1 on line 285 . Leading parallel to the railway track, the tram track would reach Kobierzyce. At this station, the trams would follow the tracks of tracks 6.8. (Figure 11, 12). 


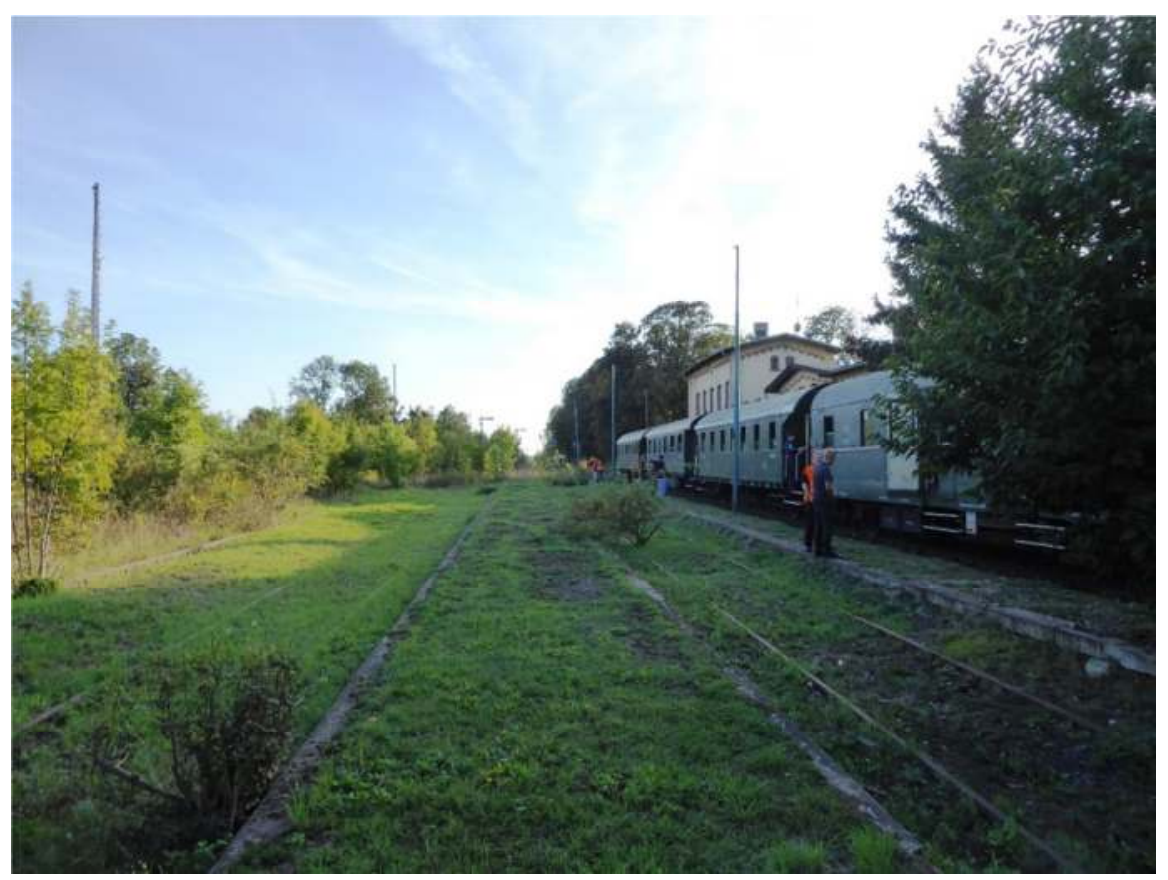

11. View of platform 3 of the station Kobierzyce between tracks 2 and 4, the train stands on track 1

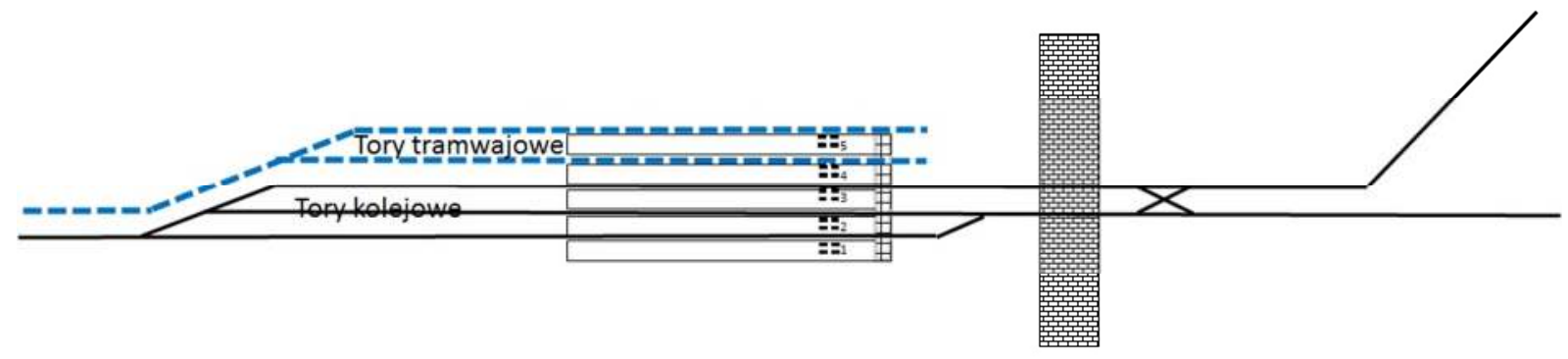

12. Proposed use of the station Kobierzyce

In the area of any other railway station there would be a tram pass with turnouts set on keys with permanently set traffic lanes. I believe that it is possible to adopt the principle that every tram would pass by the one going from the other side on the right-hand side of the road. Similarly, a tram from the other direction would always go down on its right-hand side. This would ensure a high level of safety on maintenance-free passages without a remote control. The number of passes will result from the assumed frequency of movement. Recommended frequency of courses in each direction is every 20 minutes at the peak and every 30 minutes outside the peak. Ultimately, the tram from Kobierzyce would end its route on the Krzyki loop in Wrocław, where passengers would have to change to other lines. The change of driving direction would take place in the tram depot Borek. It is connected with the possibility that in a short time the demand will exceed the supply and it will be necessary to double the stock of Skoda 19T trams. Such a long tram depot would cause great problems on a heavily loaded route from the Krzyki loop to the Świdnicka stop and further on, e.g. Piłsudskiego Street.

The construction of a tram line to Kobierzyce would increase the accessibility of public transport. Only in Kobierzyce can one more tram stop be built at Sportowa Street. Between Kobierzyce and Domasław there could be a bus stop in Chrzanów at Jesionowa Street to Magnicka Street. In Domasław it is worth to build two stops: at Topolowa Street and Czereśnowa Street. Residents of Bielany Wrocławskie could give up their cars when going to 
Wrocław, because only in this town there is a possibility to build three tram stops: at Śnieżna Street, Spring Street and Two Worlds at the Ślęza Recreational Centre. The average distance of the stops would be 450-900 m. This is not enough for a diesel railcar, because of the dynamics of this vehicle over short distances between stops. It's normal for a tram. The construction of a tram line, the Krzyki stop in Wrocław - Kobierzyce, would significantly change the transport behaviour of the inhabitants of the above mentioned towns and cities. This would also have an impact on property prices. This would result in a new quality of settlement in these towns. The cost of this project is about PLN 150 million.

\section{Summary}

The presented proposals for new railway lines and new tram tracks are aimed at improving the accessibility of public transport for the inhabitants of Lower Silesia. The implementation of the proposed investments requires more detailed analysis. It is a starting point for a broader discussion on whether it is worth spending PLN 30 million to reduce the travel time by 8 minutes. However, it is worth remembering that we are at the last moment in our lives, when we can count on greater funding from the European Union. The proposed new routes are expensive to build, but they have not only a financial but also a social dimension. They prevent the so-called exclusion of access to public transport for the inhabitants of Lower Silesia.

\section{Source materials}

[1] Bartodziej Mariusz: Lower Silesia: Even almost half a billion for the renovation of the Wrocław - Świdnica section. PKP PLK will announce the second tender?, nvestmap.pl, 2018-12-06 07:38:27, https://investmap.pl/dolny-slask-nawet-niemal-pol-miliarda-zaremont-odcinka-wroclaw-swidnica-pkp-plk-oglosza-drugi-przetarg.a144810

[2] Express-Miejski.pl : railway line is being liquidated, commune Ząbkowice Śląskie:, 201409-23, http://zabkowice.express-miejski.pl/wiadomosc/18394,ongoing-liquidation-linesrailways

[3] National Railway Base, https://www.bazakolejowa.pl/index.php

[4] Organiściak Jerzy, Grygorcewicz Bartosz, Dziedzic Marcin: Ząbkowice Śląskie 12872007: people, dates, facts, Wyd. Lokalna Organizacja Turystyczna Ziemi Ząbkowickiej 2007, ISBN 978-83-925313-0-2

[5] PKP PLK, Design and execution of construction works within the framework of the project entitled: "Revitalization of railway line no. 285 on the section Wrocław G1. Świdnica Przedmieście with line no. 771 Świdnica Przedmieście - Świdnica City, 201810-03, zamowienia.plk-sa.pl

[6] Sakowska Magdalena: Line no. 285 (and 286) Wałbrzych-Jedlina: everything begins, https://walbrzych.dlawas.info, 26.10.2018, https://walbrzych.dlawas.info/wiadomosci/linia-nr-285-i-286-walbrzych-jedlinawszystko-sie-zaczyna/cid,18349, a

[7] Marshal's Office of the Lower Silesian Voivodship: Resolution No. 219/VI/19 of the Lower Silesian Voivodship Board dated 9 January 2019 on granting consent to take over for the Lower Silesian Voivodship Authority the right of perpetual usufruct of land and ownership rights to buildings and equipment connected with railway lines No. 284, 291, 310,318 and 327

[8] Ząbkowice

Śląskie, https://semaforek.kolej.org.pl/wiki/index.php/Z\%C4\%85bkowice_\%C5\%9Al\%C4\%85ski e 